\title{
Development of Learning Tools Mathematics Based Problem Based Learning (PBL) for Improving Mathematical Problem Solving Ability of Grade VII Junior High School Students
}

\author{
$1^{\text {st }}$ Nunung Septriani \\ Mathematics Department \\ Universitas Negeri Padang \\ Padang, Indonesia \\ krunyung@gmail.com
}

\author{
$2^{\text {nd }}$ I Made Arnawa \\ Mathematics Department \\ Universitas Andalas \\ Padang, Indonesia \\ arnawa1963@gmail.com
}

\author{
$3^{\text {rd }}$ Ermanto \\ Faculty of Lingustics and Arts \\ Universitas Negeri Padang \\ Padang, Indonesia \\ ermanto@fbs.unp.ac.id
}

\begin{abstract}
Problem solving ability is one of the important abilities for students. But in fact problem solving ability is still low. Problem Based Learning (PBL) is one of the models that can develop problem solving abilities. Learning tools is one important component in learning. The Learning Tools used has not yet been seen to develop student problem solving abilities. The purpose this research to know the characteristics of learning tools based on PBL using Plomp model. The result of this research is learning device has valid.
\end{abstract}

Keywords-Learning Tools, Problem Based Learning, Problem Solving Ability

\section{INTRODUCTION}

Mathematics is one of the sciences that is always learned at every level of education, from elementary school, high school to college. Mathematics is one of the conditions in determining student graduation. Mathematics is also a basic knowledge needed to support students' success in higher education. This shows that mathematics has a very important role in the world of education. In general, there are five aspects of standard abilities that students should have in learning mathematics. Five aspects of the ability of these standards are generally is problem solving, reasoning ,communication skills,the ability of the connection,and the ability of representation[5].

Problem solving ability is one of the mathematical abilities that has an important role in the success achieved by students. The problem solving has been the main focus of mathematics education reform for more than 20 years[7]. In survey of mathematics and science education in Bandung sponsored by JICA explained "mathematical problem solving is one of the important mathematical activities by teachers and students at all levels from elementary school to High school "[8].

Similar things are explained "problem solving is a skill that needs to be taught, and the math teacher must make an effort for it"[9]. But the reality is very different. Many teachers still have difficulty organizing learning so that students have problem-solving skills, many students experience difficulties in solving mathematical problems[4].

In line with the above opinion, things that are not much different from the authors found in the field when carrying out observations at SMPS Naga Sakti, Tapung Hilir Subdistrict, Kampar Regency. In terms of students, it was concluded that students had difficulties when faced with high-level thinking problems such as problem solving. Students often do not understand the true meaning of a problem, so students cannot plan the problem solving strategy appropriately. Therefore the solutions obtained by students are also inappropriate.

Mathematical learning that occurs has not emphasized the effort to construct students' knowledge. Learning is still dominated by teachers, the learning steps carried out are routine steps, such as: the teacher gives a concept accompanied by examples of questions, then students are asked to work on the exercises contained in the Student Worksheet. During the learning process, it can be seen that the teacher does not get used to learning problems that present problem solving. Teachers still have not utilized problem solving abilities as targets in mathematics learning.

When given a test question to see problem-solving abilities, there are still few students who are able to achieve the ideal score of each problem solving indicator. This shows that the students' mathematical problem-solving abilities represented by these indicators are still low and need to be improved. To overcome the low problem solving ability, a learning model is needed, where the characteristics and steps of the model must be able to teach students mathematical problem solving skills. One of the suitable learning models to overcome the problems is Problem Based Learning (PBL).

PBL is learning that encourages deeper understanding of the material and is also a problem based learning where students not only get basic knowledge when learning but also experience how to use their knowledge to prove real-world problems [1]. PBL aims for students to get autonomous learning, independent learning, inquisition and problem solving skills, where individuals are faced with situations such as those they face in their daily lives and are encouraged to study individually through self-study and 
research [3]. Hmelo-Silver et al. [2] states that PBL is a set of teaching models that use problems as a focus for developing problem solving, material, and self-management skills. PBL has three characteristics, namely (1) learning focuses on problem solving, (2) the responsibility to solve problems rests on students, and (3) the teacher supports the process when students work on problems [2].

The material in the mastery process requires problem solving ability, one of which is social arithmetic material. The material of social arithmetic is one of the material in the competency standard of grade VII of the first semester of junior high school which is very close to its daily life. This material needs to be studied to develop students' ability to solve daily life problems, especially in economic activities (trade). Learning this social arithmetic material should be done constructively in accordance with the changing paradigm of today's learning. PBL is a learning model based on constructivist learning theory. In constructivist learning theory students connect new knowledge with prior knowledge and construct new meanings. Thus, relevant social arithmetic material is taught with PBL.

The implementation of graderoom learning basically requires a learning tool for its operation. For the implementation of learning, a Lesson Plan (LP) is needed as well as a Student Worksheet (LKS) which must be adapted to the life context faced by students and strived to be able to facilitate students in expressing their thinking abilities. But in reality in the field, based on the analysis of researchers on the LP that was compiled and used by teachers, there were still some weaknesses. LP used by the teacher has used a model or approach to learning but the steps and learning activities have not specifically described the learning process in the material that being taught. In the LP, activities that activate students have not been shown, and have not been seen to teach students problem solving skills.

Another component of Learning Tools that have no less important role as LP is LKS. LKS should be designed so that it makes students more active and can work independently to explore their abilities. In reality, the worksheets used in schools are ready-made worksheets that are widely traded and the contents are more directed to the conclusion of the material rather than student activities or activities. Besides that, between LP LKS is less synchronous, the LKS should be used referring to the LP made by the teacher. The worksheets used contain practice questions not contain problems that can train students' thinking skills. LKS has not been able to activate students and train students to work independently.

\section{RESEARCH METHOD}

The study is a research \& development (Research and development). The model used is a model development Plomp which consists of three phases, namely: a preliminary analysis phase, phase of development or manufacture of prototypes and assessment phase [6]. In the phase of the preliminary analysis carried out a needs analysis, curriculum analysis, concept analysis, and analysis of the students. The results of the preliminary analysis phase of analysis used as the basis for development PBL based learning device. In the prototype phase of development or manufacture to design learning device, evaluation and revision of the prototype through formative evaluation stages comprising its own evaluation, assessment specialists or experts, individual evaluation, and the evaluation of the small group. Later in the assessment phase conducted field tests to look at the practicalities and effectiveness.

This study is only done through development or prototype namely the validity stage. Because the goal of this study to determine the validity of the learning device based Problem Based Learning (PBL). Instruments used in this study is guideline interviews, checklists, questionnaires, evaluation sheets and sheets validas experts themselves. Before the instrument is used, each instrument validated by experts. The valid instrument used in the study. The results were analyzed according to the type of data. The Qualitative and quantitative data were analyzed and categorized so it can be taken qualitative conclusions.

\section{RESULTS AND DISCUSSION}

\section{Preliminary Reseacrh}

Learning based on Problem Based Learning (PBL) tools are prepared based on preliminary analysis or preliminary investigation. The preliminary analysis activity begins with conducting needs analysis, curriculum analysis, concept analysis and student analysis. Needs analysis is done to collect the information needed in development of mathematics Learning Tools based on Problem Based Learning (PBL). Information was collected at Naga Sakti Public High School in Tapung Hilir Subdistrict through observes activities, interviews with mathematics teachers and gives student questionnaires.

Based on observations and interviews conducted on the seventh grade mathematics teacher at SMPS Naga Sakti, some information was obtained, namely: in the process of mathematics learning carried out still dominated by the teacher, the learning steps carried out were routine steps, such as: teacher give concepts accompanied by examples of problems, then students work on the exercises contained in the LKS. The teacher does not get used to presenting questions to train students' problem solving skills. So that students experience difficulties when faced with problem solving problems.

Learning tools used in the learning process in the form of LP, textbooks and worksheets are ready to use which are obtained from certain institutions. The lesson plan used by the teacher has not specifically described the learning steps in the material being taught. In LP, activities that activate students are not yet illustrated, and have not been seen to teach students problem solving skills. In other words, the LP prepared by the teacher has not been conditioned by the needs of students. The worksheets used in the school are more directed to the conclusion of the material rather than the activities or activities of students. The LKS used contains practice questions not containing problems whose completion steps can train students' thinking skills. LKS also has not been able to activate students and train students to work independently. In addition the stages in the LKS are not in accordance with the stages of learning activities in the LP that the teacher makes.

The information obtained further is about students' understanding of the material that has been learned. According to the teacher, students 'abilities are very diverse, students' understanding of the material depends on their interest and attention during the learning process. There are still many students who consider mathematics difficult 
because many formulas are used. According to the teacher's explanation, some students could not understand the material well, but they did not dare to ask questions about the subject matter they did not understand because they felt embarrassed and afraid to ask questions.

At the stage of curriculum analysis a review of the education unit level curriculum (KTSP) was applied in schools for mathematics subjects in grade VII SMP on social arithmetic material. Curriculum analysis is done by observation using an instrument in the form of a checklist. This analysis is in the form of determining indicators of social arithmetic materials that will be developed in LP and Student Workseet. Explanation of Standard Competence (SC), Basic Competence (BC), and indicators of achievement of competency into consideration to determine the concepts needed in learning mathematics and measuring the achievement of SC and BC. The results of the SC and BC analysis contained in the content standard are translated into indicators of achievement of competence. The results of the elaboration of competency achievement indicators for basic competencies in social arithmetic materials can be seen in Table 1.

TABLE 1. IndiCATORS OF COMPETENCE ACHIEVEMENT IN SOCIAL ARITHMETIC MATERIALS BASIC

\begin{tabular}{|c|c|}
\hline $\begin{array}{c}\text { Basic } \\
\text { Competencies }\end{array}$ & $\begin{array}{c}\text { Indicators of Achievement of } \\
\text { Competencies }\end{array}$ \\
\hline $\begin{array}{l}\text { Resolving } \\
\text { problems } \\
\text { related to social } \\
\text { arithmetic } \\
\text { (sales, } \\
\text { purchases, } \\
\text { profits, losses , } \\
\text { discount, gross, } \\
\text { tara, net, single } \\
\text { interest, and } \\
\text { tax). }\end{array}$ & $\begin{array}{l}\text { 1. Understand the concept of overall } \\
\text { value, unit value, and partial value. } \\
\text { 2. Resolve problems related to overall } \\
\text { value, unit value, and partial value. } \\
\text { 3. Understand the relationship between } \\
\text { sales prices, purchase prices, profits, } \\
\text { and losses. } \\
\text { 4. Resolve problems related to sales } \\
\text { prices, purchase prices, profits, and } \\
\text { losses. } \\
\text { 5. Resolve problems related to profit and } \\
\text { loss percentages. } \\
\text { 6. Determine the concept of rebates } \\
\text { (discounts). } \\
\text { 7. Resolve problems related to rebates } \\
\text { (discounts). } \\
\text { 8. Determine the concepts of gross, tara, } \\
\text { and net. } \\
\text { 9. Resolve problems related to gross, tara, } \\
\text { and net. } \\
\text { 10. Determine the concept of single interest } \\
\text { and taxes in economic activities. } \\
\text { 11. Resolve problems related to single } \\
\text { interest and taxes. }\end{array}$ \\
\hline
\end{tabular}

The description of competency achievement indicators is done so that the social arithmetic material that will be taught can be explained in order so that it is easily understood by students. Based on the elaboration of SC and BC it is arranged a mathematics learning device based on Problem Based Learning (PBL) in the form of LP and LKS.

The next stage is concept analysis, this analysis aims to determine the content and subject matter needed in the development of learning tools, by identifying the main concepts taught, detailing and compiling them systematically. Concept analysis is done by observing using an instrument in the form of a checklist. The results of concept analysis are arranged in the form of concept maps as in Fig. 1 below.

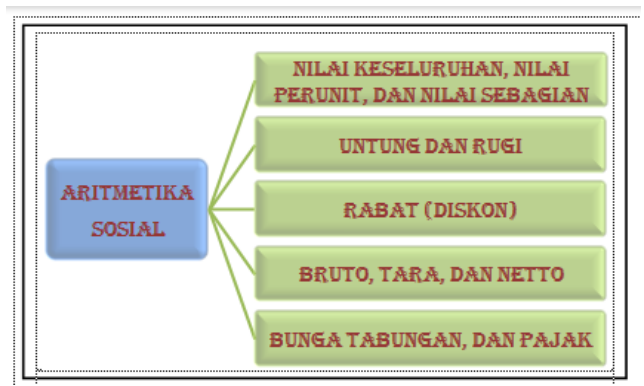

Fig. 1 Concept Map of Social Arithmetic Materials

The last stage carried out in the preliminary analysis activity is student analysis. This analysis is conducted to examine students by identifying the characteristics of students so that the Student Worksheet is designed according to what students want. In this analysis phase the researcher distributes questionnaires relating to the implementation of mathematics learning, students' tendency to follow learning, learning resources, and other things that describe the characteristics of students.

The questionnaire results show that students consider mathematics a useful lesson for everyday life, but students have difficulty understanding the topic and solving problems in the form of story problems. Students prefer the group learning system, are more likely to ask friends than to ask the teacher, more dominantly love the learning resources student worksheet which are green and blue with the size of the student worksheet such as the size of the ordinary worksheet, namely A4 and accompanied by an interesting picture according to the material. The implementation of the stages or steps of learning in the worksheet is detailed and clear, so that students in groups can understand and remember the material being studied well, and if students experience difficulties the teacher is ready to help.

Based on the analysis, the researcher develops learning tools that can support learning activities that enable students to be active and facilitate habits and accommodate the characters possessed by students in improving their abilities, especially problem solving abilities.

PBL-based Learning Tools begins by presenting problems to students so that students can practice their thinking skills in solving problems. Worksheets contain student activities in understanding concepts through questions that guide and direct students to the material being studied. Students will follow instructions based on answers to questions students make, so students can understand the concepts being studied in their own way or discuss with friends. After the group discussion is over the students are given the opportunity to present their work by presenting it in front of the grade, so that students are trained in expressing their opinions. At the end of the activity students are asked to make conclusions about the material that has been learned.

\section{The development phase or Prototyping Stage}

\section{a. Results Design Prototype}

Based on a needs analysis, curriculum analysis, analysis of the concept and analysis of the students, then designed devices based learning Problem Based Learning (PBL), 
which is implemented in the 1st half of the grade VII social arithmetic material. This learning device is designed based on the characteristics of learning based on Problem Based Learning.

\section{1) Design of Lesson Plans (LP)}

Lesson Plans (LP) are designed as guidelines for teachers in carrying out learning activities. The LP is systematically designed which contains the components of writing LP in accordance with the standards of basic and secondary education processes. LP is designed by paying attention to the linkages and integration between $\mathrm{SC}, \mathrm{BC}$, indicators of competency achievement, learning objectives, teaching materials, learning methods, learning resources, learning activities, and assessment to be a whole learning experience for students. The steps of learning activities consist of 3 activities, namely preliminary activities, core activities, and closing activities. The core activities presented in the lesson plan refer to PBL-based learning which consists of five phases of activity, namely orienting students to problems, organizing students to study, guiding individual or group investigations, developing and presenting work, and analyzing and evaluating the problem solving process. Activities in this LP are also integrated in PBL-based LKS.

\section{2) Designing Student Worksheets (LKS)}

The LKS design includes didactic aspects, content aspects, graphic aspects or appearance, and aspects of language. The presentation of worksheets begins with providing problems related to daily life in accordance with the material being studied. Presentation of the problem is accompanied by an image that matches the problem. Students are asked to read and understand the problem given. Examples of presentation can be seen in Fig. 2.

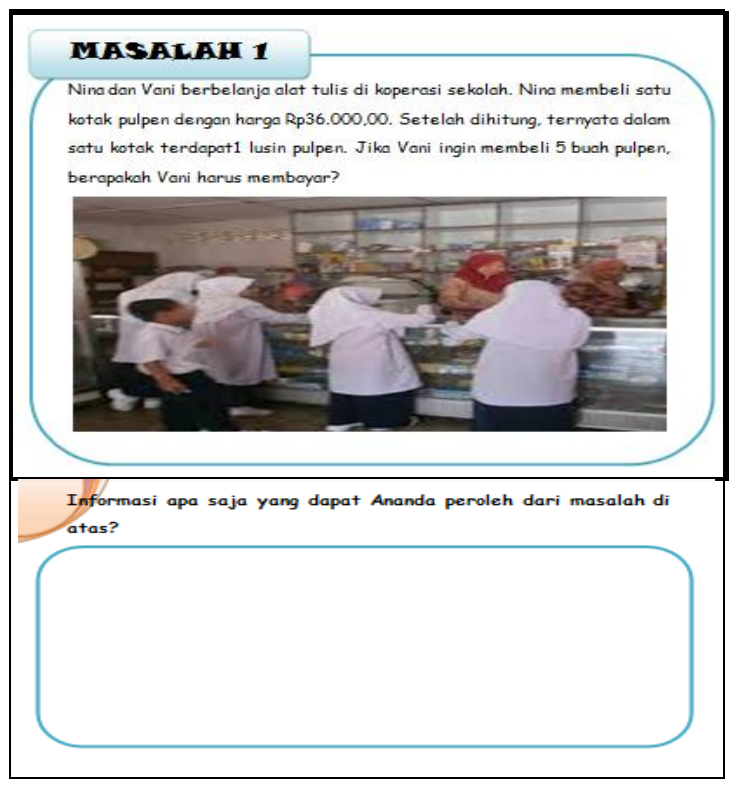

Fig. 2 Example of Design Student Orientation Activities Problems on Student Worksheet PBL

In the activity of guiding individual or group investigations, students are asked to discuss with the aim of obtaining the information needed to find solutions to the problems given. Examples of presenting activities to guide individual or group investigations can be seen in Fig. 3 .

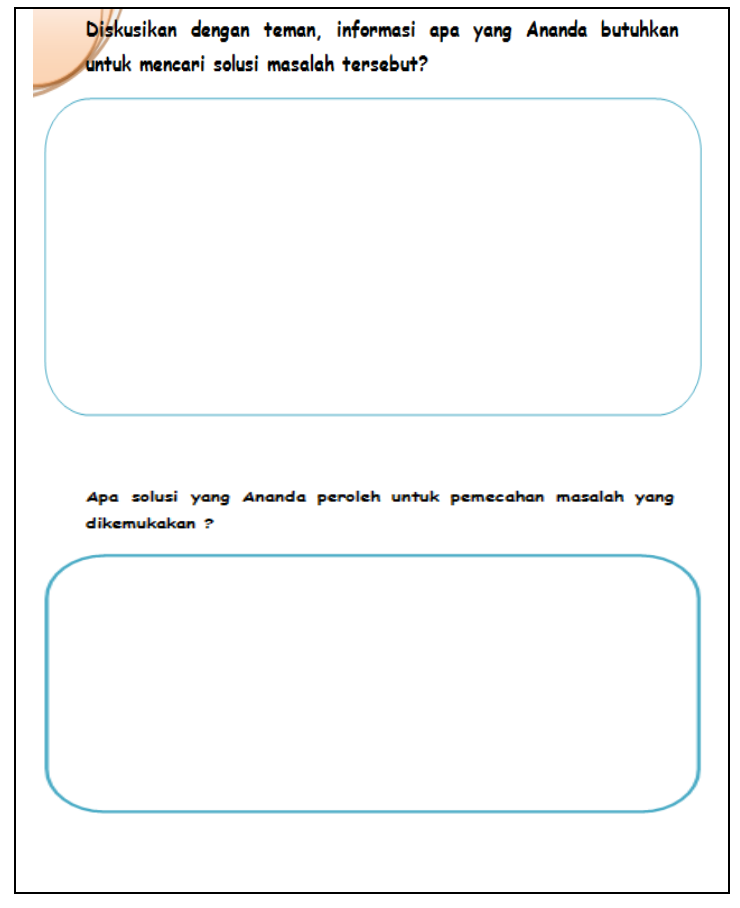

Fig. 3 Examples of Design Activities Guiding Individual and Group Investigations in LKS

In developing and presenting work, students were asked to present the results of their group discussions in front of the grade. This activity is also accompanied by a grade discussion to provide responses related to the results of the group presentations that appear and complete information that has not been conveyed. Examples of activities to develop and present the work can be seen in Fig. 4.

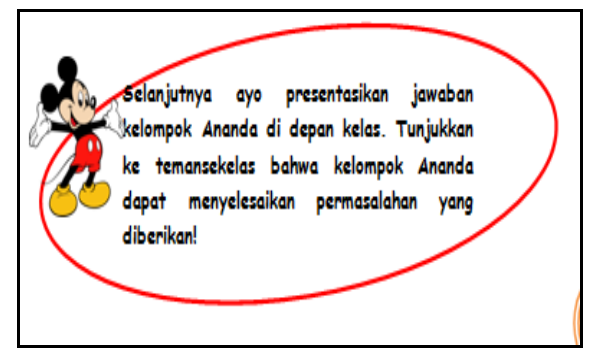

Fig. 4 Examples of Activity Design Developing and Presenting Work on LKS PBL

Next, students are asked to solve problems (exercises) in the training section. This activity aims to make students better understand the material they have learned. Examples of the problems given in the let's section practice as shown in Fig. 5 below. 


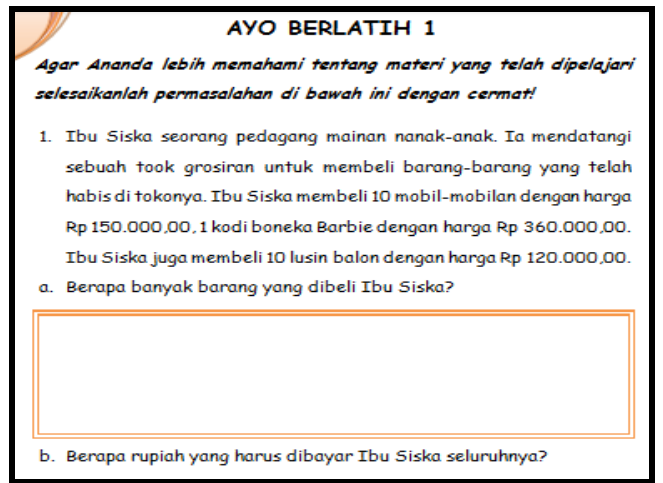

Fig. 5 Example of a Let's Practice Activity on LKS PBL

Problems and activities presented on worksheets correspond to indicators of achievement of competencies. Kegrafikaan aspect or appearance of worksheets designed made include: a cover page /cover,writing and drawing. The cover /cover page contains the identity or title of the worksheet based on Problem Based Learning PBL, subjects, and the student identity column as the owner of the LKS. In addition, in the cover there are also several images related to mathematics. The color chosen for Cover LKS is dominant in green. This color selection is in accordance with the results of the analysis of students who like green, using A4 paper (size $29.7 \mathrm{~cm} \times 21 \mathrm{~cm}$ ).design cover PBL based LKS can be seen in Fig. 6 .

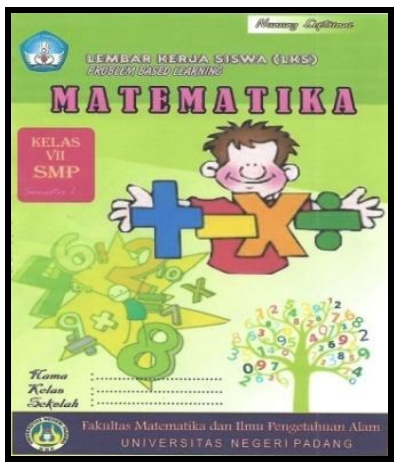

Fig. 6 Design of Cover LKS based on Problem Based Learning (PBL)

LKS designed using standard language in accordance with enhanced spelling (EYD). LKS uses simple and communicative language and is in accordance with the level of understanding of grade VII students of junior high school so that the presentation of student worksheets can be understood by students well. After the PBL-based learning device design is complete, proceed to thestage self evaluation to check the completeness, needs and errors in the device made. Designed by the learning device at this stage is prototype $\mathrm{I}$.

\section{b. Results of Self Evaluation}

The first activity undertaken after designing the learning device is a self-evaluation (evaluation itself). Before consulting and discussing with experts, self-evaluation is conducted on the learning tools that have been designed. In LP there are several aspects that are evaluated, including typing errors, accuracy of the use of punctuation, and accuracy of the use of words or terms. Aspects that are evaluated on the LKS include typing errors, accuracy of punctuation, accuracy of the use of words or terms, accuracy of writing size. In general, many errors occur in typing words and accuracy of punctuation.

After self evaluation, revisions were made to learningbased devices PBL that has been designed. Then the results of improvements from the prototype I were consulted and discussed with competent experts or experts to be validated.

\section{c. Validation Results of Expert Learning Tools The}

LP validation was carried out by three experts, namely two mathematics lecturers and one Indonesian lecturer. During the validation process there are several revisions suggested by the validator. The validation results of LP PBL as a whole have met valid criteria with an average validity index of 0.96 .

Worksheet validation based on Problem Based Learning was carried out by four experts, namely two mathematics lecturers, one Indonesian lecturer, and one educational technology lecturer. During the LKS validation phase there are several revisions made based on suggestions from the validator. The LKS validation results show that the PBLbased worksheets developed have an average validity index of 0.94 for didactic and material aspects, 0.67 for linguistic aspects, and for graphic or display aspects have an average validity index of 0.67 with a valid category . Overall the validation results of LKS based PBL have met valid criteria with an average validity index of 0.76 . So it can be concluded that the learning tools in the form of LP and LKS based on Problem Based Learning (PBL) developed are valid.

\section{CONCLUSION}

Based on the research that has been carried out, the results show that the mathematics learning device based on Problem Based Learning (PBL) is developed for students grade VII who in the first semester have met valid criteria. It is expected that there will be further testing in other schools to see the practicality and effectiveness of Learning Tools based on Problem Based Learning (PBL).

\section{ACKNOWLEDGMENT}

The researchers wish to thank all those who have helped make this research can be resolved properly. Thank you for your guidance, advice, and guidance of lecturers and professors validator. Thank you for your permission and cooperation in conducting research from a large family of SMPS Naga Sakti Tapung Hilir Subdistrict Kampar regency.

\section{REFERENCES}

[1] Bilgin. Ibrahim, "The effects of Problem Based Learning Intruction on University Student' Performance of Conceptual and Quantitative Problems in Gas Conceps", Eurasia Journal of Mathematics, Science \& Technology Education, vol. 5, pp. 153-156, 2009.

[2] Eggen. P, \& Kauchak. D, Strategi dan Model Pembelajaran: Mengajarkan Konten dan Kemampuan Berpikir, Terjemahan oleh Satria Wahono, Jakarta: Permata Puri Media, 2012.

[3] Karaduman, "The Relationship Between Prospective Primary Mathematics Teachers' Attitudes Towards Problem-Based Learning And Their Studying Tendencies", International Journal on New Trends in Education and Their Implications, vol. 4 pp. 145-151, 2013. 
[4] Krismanto. A, \& Wibawa. A.D, Pembelajaran Kemampuan Pemecahan Masalah BangunDatar di SMP, Kementerian Pendidikan Nasional. Pusat Pengembangan dan Pemberdayaan Pendidik dan Tenaga Kependidikan (PPPPTK) Matematika, 2010.

[5] National Council of Teachers of Mathematics, Principle and Standard for School Mathematics. Reston: NCTM, 2000.

[6] Plomp. T, and N. Nieveen, Educational Design Research, Enshede: SLO, 2013
[7] Rikard. Anthony, "Evolution of a Teacher's Problem Solving Instruction: A Case Study of Aligning Teaching Practice with Reform in Middle School Mathematics", Research in Midle Level Education, vol. 29 pp. 1-15, 2005.

[8] Suherman. E, et al, Strategi Pembelajaran Matematika Kontemporer. JICA, Bandung: Universitas Pendidikan Indonesia Press, 2003.

[9] Wardhani. S, et al, Pembelajaran Kemampuan Pemecahan Masalah Matematika di SMP, Pusat Pengembangan dan Pemberdayaan Pendidik dan Tenaga Kependidikan (PPPPTK) Matematika, 2010. 